\title{
The aniversity of Chicago
}

\section{MORPHOLOGY OF RUMEX CRISPUS}

\author{
A DISSERTATION \\ SUBMITTED TO THE FACULTY \\ OF THE OGDEN GRADUATE SCHOOL OF SCIENCE \\ IN CANDIDACY. FOR THE DEGREE OF \\ DOCTOR OF PHILOSOPHY \\ DEPARTMENT OF BOTANY \\ BY \\ WINFIELD SCOTT DUDGEON
}

Private Edition, Distributed By

THE UNIVERSITY OF CHICAGO LIBRARIES

CHICAGO, ILLINOIS

Reprinted from

The Botanical Gazette, Vol. LXVI, No. 5

November 1918 
Digitized by the Internet Archive in 2017 with funding from

University of Illinois Urbana-Champaign Alternates

https://archive.org/details/morphologyofrume00dudg 


\section{T H E}

\section{Botanical Gazette}

\section{NOVEMBER I9I8}

\section{MORPHOLOGY OF RUMEX CRISPUS}

CONTRIBUTIONS FROM THE HULL BOTANICAL LABORATORY 244

WINFIELD DUDGEON

(WITH PLATES XVII-XIX AND TWENTY-ONE FIGURES)

\section{Introduction}

A chance examination of a stem of Rumex crispus L. showed the presence of well developed internal bundles. Since this character is to be regarded as advanced, Dr. W. J. G. LAND suggested that it might be of interest to investigate the morphology of the entire plant. This paper is concerned only with an account of the morphology of the floral structures; a study of the vascular situation is already under way.

Aside from monographs, the genus Rumex, and indeed the entire family Polygonaceae and order Polygonales, have received little attention. FINK (3) made a study of the ovular structures in $R$. verticillatus L. and $R$. mexicanus Meisn. (R. salicifolius Man.), which develop very similarly. The archesporial cell cuts off a primary wall cell, then forms a linear tetrad, the innermost megaspore of which functions. He found approximately 24 chromosomes in the spindle of the first division of the megaspore mother cell, but was not certain whether this was a true reduction division. A regular 8-nucleate embryo sac is formed, and pollen tubes enter, although actual fusion of the gametes was observed but once, and that in an unfavorable preparation. Rотн (8) investigated several European 
species of Rumex, among them $R$. crispus. He found the haploid number of chromosomes in the microspore mother cells to be 8 in $R$. Acetosa, $R$. hispanica, $R$. arifolius, and $R$. nivalis; $\mathrm{I} 6$ in $R$. Acetosella; and probably 40 in $R$. cordifolius. $R$. Acetosa apparently undergoes reduction in the megaspore mother cell, although he saw no indication of subsequent fertilization. The embryo sac very frequently degenerates. He found evidence of apogamy in some species, and thinks it probable that, at least in the group Acetosa, this has been the result of dioecism. Strasburger (9) early investigated Polygonum divaricatum, and his figures of the origin and development of the embryo sac have become a classic example of normal behavior.

\section{Material and methods}

Inflorescences and individual flowers of various ages were collected along street borders near the University of Chicago, and in a flood plain pasture near Mineral Springs, Indiana, during the summers of r915 and rgr6. They were killed in chrom-acetic, imbedded in paraffin, and cut in the usual manner. Both iron alum-hematoxylin and safranin-gentian violet were employed for staining.

Some of the most important features of the morphology became apparent in the course of the investigation during the winter of I9I6-I7, and as no more material could be obtained then, there remain some points the solution of which requires the collection of more flowers and careful observations on the growing plants.

\section{Normal development}

Organogeny.-The young inflorescence of Rumex crispus is closely invested by the sheaths of successive bracts. It is profusely branched, and the branches bear flower buds of considerable size before they emerge from the protecting sheaths. All the young parts are covered with a mucilaginous secretion, rendering the penetration of reagents slow.

The flowers are borne in clusters at the nodes. The oldest are nearest the main stem, while the successively younger arise outside these, on the upper surface of the enlarged projecting nodes. 
The sequence of development of the floral organs is centripetal, although the petals and carpels are somewhat delayed (figs. I-7). The sepals appear as 3 thick prominences, and rapidly grow up over the young flower. The 3 petals appear almost simultaneously with the stamens, which they closely resemble at first (figs. 3, 8, 9). The 6 stamens appear in pairs, the 2 of each pair arising so close together that their bases are joined to each other and to the sepal opposite which they lie (fig. 9a). The carpels first appear as a thick ring about the base of the nucellus, but the latter develops much more rapidly and is not inclosed by them until the megaspore mother cell is considerably enlarged (figs. 4-7). The carpels develop as a continuous ring led by 3 growing points (fig. 8), until the ovarial cavity is inclosed, when the 3 points continue separately to form the styles and stigmas (figs. 6, 7). The styles are reflexed so that the much branched stigmas are finally placed between the bases of the anthers.

The inner integument appears during the prophase of the first reduction division (fig. 6), and the outer appears with the homoiotypic division (fig. 7). Both are 2-layered from the beginning. The inner grows up beyond the nucellus, and turns inward to close up and form the micropyle. The outer integument never extends much beyond the tip of the nucellus. During the development of the embryo sac, the cells of the outer layer of the outer integument and the epidermis of the ovary thicken, lose their contents, and form a continuous impervious layer (fig. 7; see also figs. I3, I4). This process is significant, because it leaves only the chalazal region of the ovule as a point of intake for nutrient materials.

Megasporogenesis. - The terminal cell of a definite axial row in the nucellus enlarges as the archespore (fig. 22). It soon divides to form the primary parietal cell and the megaspore mother cell (fig. 23). The parietal cell divides twice by anticlinal walls to form a cap of 4 cells. (figs. 24,28 ). Occasionally any or all of these cells may divide by a periclinal wall (figs. 25, 32). Less frequently, a cell or two of the adjacent epidermis may also divide periclinally (figs. 33, 36, 44). Occasionally there are two archesporial cells, and in one ovule there was a mass of probably 7 archesporial cells, a few of which had undergone the first division. In the most 

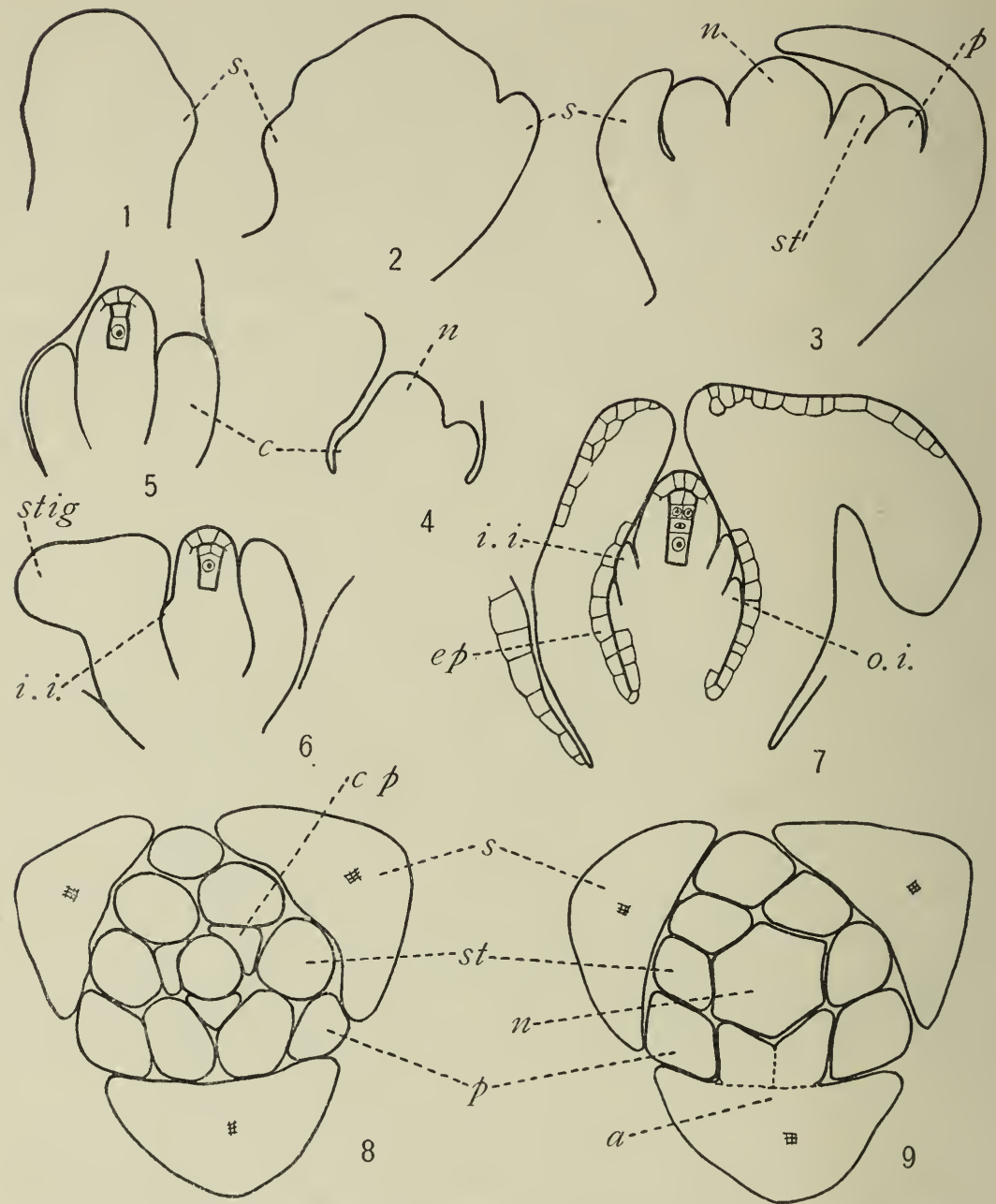

FIGS. I-9.-Organogeny: fig. I, appearance of sepals $(s)$; figs. 2, 3, simultaneous appearance of petals $(p)$ and stamens $(s t)$, nucellus $(n)$; figs. 4, 5, early development of carpels $(c)$; fig. 6 , appearance of inner integument (ii) and beginning of stigma (stig); fig. 7, appearance of outer integument (oi) and early thickening of epidermal cells $(e p)$ over outside of ovule and walls of ovary; figs. 8,9 , transverse sections of same flower, showing relation of parts, growing points of carpels $(c p)$, and union of stamens to each other and to sepal (a); figs. I-7, $X_{\text {I } 75} ;$ figs. $8,9, X_{55}$. 
advanced case observed, the 2 megaspore mother cells had fully enlarged and were in prophase of the heterotypic mitosis (fig. 24). They were separated by a crushed cell of equal length, which may have been a megaspore mother cell, but more probably was only a vegetative cell that became so crushed that it could not divide, and was forced to elongate with the enlarging mother cells.

The megaspore mother cell enlarges and elongates considerably, then undergoes two successive divisions to form a tetrad of cells (fig. 28). Apparently this division is a true reduction, for all the stages seem to be normal, and at diakinesis there are 32 pairs of chromosomes (fig. 26). While an accurate count of the chromosomes could not be made on the spindle, careful estimation indicates that the number still is 32 (fig. 27). In the vegetative cells the spindle is shorter, and proportionally much broader, and while the chromosomes are too small and too densely massed to be definitely counted at any stage, they clearly are more numerous than in the megaspore mother cell; I could only estimate that there are about twice as many, that is, 64 .

Wall formation follows each of the reduction mitoses. The first wall usually divides the mother cell a little above the center (fig. 30). The second wall is usually near the outer end of the inner cell (figs. 29, 30), although in the best preparation found (fig. 28) the cell is nearly equally divided. The wall in the outer cell is always longitudinal, instead of transverse (fig. 28). There is some irregularity in the sequence of the homoiotypic division; usually the inner cell divides first (fig. 30); sometimes the divisions are simultaneous (fig. 28); and in one case the outer cell was the first to divide.

The inner megaspore functions, and the others quickly degenerate (fig. 29). The third megaspore rarely forms a normal cell, and is usually the first to degenerate (figs. 3I, 33). The outer cell may degenerate before it has a chance to divide, or the 2 megaspores may degenerate before they are separated by a wall (fig. 3I).

EMBRYo SAC.-The functioning megaspore rapidly elongates and develops a large vacuole at each end, with the nucleus centrally placed (figs. 33-35). The daughter nuclei migrate to the poles, where two more mitoses produce 8 nuclei (figs. $38,42,44$ ). The 
mature sac is of the usual organization (fig. 46). The outer end enlarges greatly, crushing the parietal and adjacent nucellar cells, and comes to lie in contact with the epidermis of the nucellus. The extreme inner end remains small through this and subsequent development, and in it the 3 antipodal cells are cut off by walls. While they persist until the embryo is of considerable size, they never manifest any activity (fig. 47). The polar nuclei fuse early (figs. 44-47), and the fusion nucleus lies well toward the outer end of the sac. The egg apparatus is typical.

Development of stamens.-The stamen primordia are at first oval in cross-section (fig. 8), but early differentiation of the archesporial cells makes them somewhat rectangular, and sets off the anther region from the filament. The archespores are single rows of cells (fig. 48); each soon divides by a periclinal wall to form the primary parietal cell and the primary microsporogenous cell (fig. 49), then both divide anticlinally. Frequently the anticlinal division precedes the periclinal (fig. 50). There are 2 periclinal divisions in the primary parietal cell, and an appropriate number of transverse divisions to keep pace with the rapidly elongating anther. The first (fig. 54) sets off a layer that finally differentiates into a well marked endothecium with characteristic spiral thickenings; the second (fig. 57) forms the middle wall layer and the tapetum, and takes place about the same time as the last division in the sporogenous tissue. The middle layer is soon crushed and obliterated (fig. 58).

The tapetal cells appear to behave in all possible ways. According to BonnetT (I) the nucleus usually divides twice by normal mitoses, after which there may occur a great variety of nuclear fusions and abnormal mitoses. In some cases there is but one division. Usually in Rumex crispus the tapetum becomes binucleate; often it is multinucleate; and now and then there may appear large irregular nuclei with many nucleoli, as if formed by the fusion of a number of small nuclei (fig. 6r). Apparently the normal condition is for the tapetum to persist as a functioning nutritive layer up to the liberation of the microspores from the tetrad (fig. 63); but in keeping with the widespread degenerations occurring throughout the flower, it may begin to degenerate while 
the microspore mother cells are entering reduction (fig. 58). The cytoplasm becomes vacuolate, the nucleus stains very deeply, and shortly the entire protoplast collapses.

Before the microspore mother cell stage, the epidermis over most of the anther begins to enlarge and thicken, and the protoplasts to disorganize. This thickening extends to the cells of the connective, so that each loculus becomes inclosed by an impervious layer, except in the stomial region (fig. Io). Here a plate of the

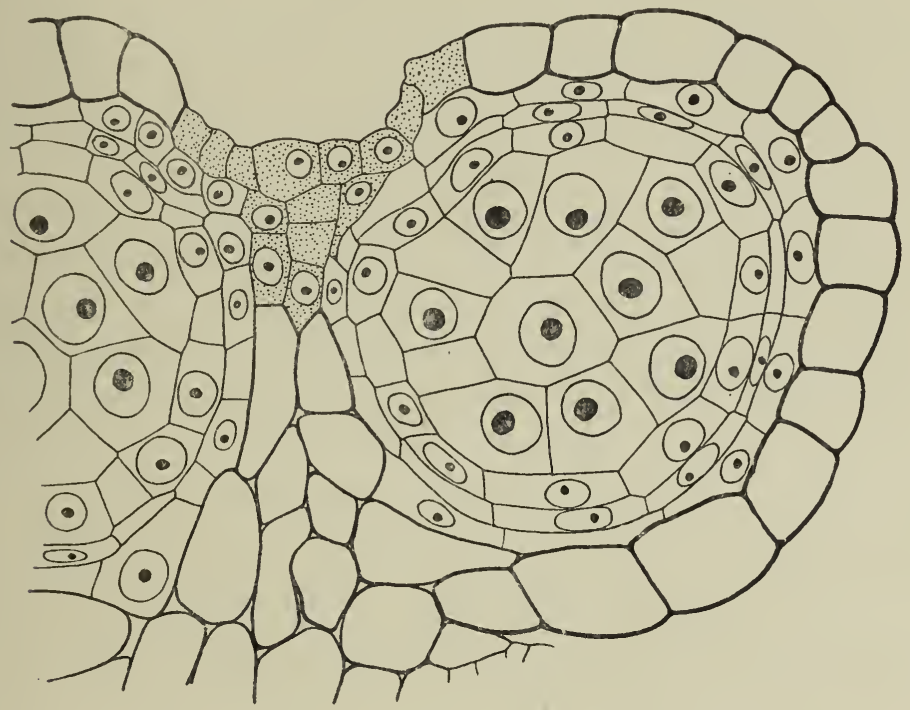

FIG. Io.-Portion of transverse section of fully differentiated anther, showing thickened epidermis continuous with thickened connective, and permanently juvenile tissue (shaded), subsequent disorganization of which first connects the two adjacent loculi, then dehisces the resulting pollen chamber; $\times_{730}$.

epidermis a few cells wide, together with the outer half of the tissue between adjacent loculi, remains undifferentiated, as a special mechanism for dehiscence. As the anther matures, these weak cells break down, first joining the cavities of the adjoining loculi to form the pollen chamber, then opening this chamber to the exterior.

Microsporogenesis.-The primary sporogenous cells undergo three or four successive divisions to form the completed sporogenous tissue. At the same time the anther has elongated greatly, 
so that in each loculus there come to be $9^{-} \mathbf{I} 2$ mother cells in transverse section, and $15^{-20}$ in longitudinal section (fig. 57). Just before reduction there is conspicuous enlargement of the anther, stretching the walls of the mother cells, and allowing the protoplasts to round off. The cytoplasm of the mother cells is rather dense and finely granular, and the nuclei are large with scanty chromatin.

Reduction appears to be normal. No attempt was made to trace the details. At diakinesis there are 32 pairs of chromosomes (fig. 60), as found in the megaspore mother cells. The formation of a tetrahedral tetrad, the development of a thick cellulose wall about it, wall formation about the microspores, and liberation of the microspores from the tetrad by disorganization of the thick common wall, all follow the usual procedure for dicotyledons. At first rather dense, the cytoplasm of the microspores does not keep pace with the enlargement of the cell, and becomes rather finely vacuolate (fig. 64). It is not certain whether this is entirely normal; indeed, degeneration is so universal that it is difficult to determine whether there is such a thing as normal development of the microspore.

The nucleus of the microspore divides into tube and generative nuclei, and the latter organizes a small cell about itself (figs. 67, 68). Before shedding, the generative cell produces two male nuclei (figs. 7I, 72); very few pollen grains ever reach this stage with anything approaching what may be considered normal appearance. The exine becomes well thickened and delicately rugose. Three germ pores are formed, beneath which the intine is slightly thickened (figs. 65, 66); they are connected with each other by furrows over the surface.

Fertilization.-Any conclusion for or against fertilization must for the present depend entirely on negative evidence. Some of the facts observed point rather conclusively to the occurrence of fertilization. There is no doubt that there is diakinesis in the megaspore mother cell, that there are 32 diads, and that this is the number present in the microspore mother cells also. While the exact number of chromosomes on the spindle of the heterotypic mitosis could not be counted, it appears to be 32 (fig. 27); the achromatic figure has all the characteristics of a reduction spindle; and finally a 
tetrad of cells results. Further, the polar nuclei fuse early, a process characteristic of normal haploid embryo sacs; and a fair number of embryos is formed. Many embryo sacs have the appearance of having waited a long time for fertilization, before finally degenerating (fig. 47). On the other hand, there is equally convincing evidence that fertilization does not occur. I cannot be sure that I have seen normal pollen in any instance; that which might be considered normal is so scarce that there seems little chance for adequate pollination. Some pollen grains have been observed on the stigmas, but they all had the appearance that is believed to indicate degeneration, and certainly none of them was germinating. At the same time, the stigmas wither early, and most of them would seem to be incapable of supporting pollen tube growth. No pollen tubes were ever observed, either in the styles or in the micropyles, nor any densely staining remains that might indicate the position of former tubes. The dead impervious layer over the outer integument would seem to preclude the entrance of pollen tubes through any other point than the micropyle and the tip of the nucellus. No fusion of gametes, which after all is the final proof of fertilization, was seen; indeed, in all the preparations I have made and examined I have seen just one embryo sac that contained a normal appearing egg apparatus (fig. 46), and it was in a still unopened flower. In the many flowers I have examined in section, only a relatively small number contained embryos.

It is possible that Rumex crispus behaves as Overton (7) found for Thalictrum purpurascens, where some megaspore mother cells undergo normal reduction, producing haploid embryo sacs and reduced eggs that require fertilization for further development, while other megaspore mother cells fail to reduce, and give rise to diploid sacs and eggs, the latter developing embryos apogamously. If this should prove to be the situation in Rumex crispus, then it would be expected that the embryos arise apogamously from unreduced eggs. I regret that there has been no opportunity to collect new material to settle this important question.

Subsequent development of Flower.-It is beside the purpose of this paper to discuss the details of fruit development, and 
only the early stages have been investigated. As previously mentioned, only a relatively small number of flowers ever proceed to fruit formation. The embryo and endosperm are of the well known Capsella type; the suspensor may become about ro cells long, and occasionally some of the cells divide longitudinally. All parts of the ovule elongate greatly, and the integuments and walls of the nucellus finally become compacted into a single thin layer. The carpels become much thickened and the cells strongly lignified. The petals enlarge and elongate to keep pace with the developing fruit, and function as protective organs (valves), while the tissue on the abaxial side of the midrib of each proliferates and forms the characteristic tubercles. The sepals alone, of all the structures in the maturing flower, fail to enlarge, and remain tiny flaps at the bases of the petals.

\section{Degenerations}

It soon became apparent that the most striking and significant feature in the flowers of Rumex crispus is the wholesale degenerations that occur. These degenerations may go on in either the stamens or the carpels, or in both at the same time. They are characterized in some cases by lighter staining and increasing vacuolation of the cytoplasm, until it becomes an almost indistinguishably thin peripheral layer, and the aggregation of the chromatin into fewer and larger masses, with irregular outline of and final collapse and disintegration of the nucleus. Such changes are characteristic in the earlier stages of development of the stamens. In other cases, the cytoplasm increases in density and staining power, and plasmolyzes away from the walls; the nucleus becomes deeply and uniformly granular, and finally stains as a solid homogeneous mass; the protoplast ultimately shrinks into a blob in which no trace of the original structure can be distinguished.

Degenerations IN THE Stamens.-Degenerations in the stamens may begin at any stage, from the primary sporogenous cell to the pollen grain, and may involve part or all of the sporogenous tissue, part or all of the microspore mother cells, one to all of the spores of a tetrad, any or all of the microspores, and any or all of the pollen grains, in any or all of the loculi of the anthers, in 
any or all of the flowers of an inflorescence, and may or may not be accompanied by disorganization of the corresponding parts of the anthers. No instance has been observed of failure of all 6 anthers to start normal development, and nothing indicating disturbances in this development appears in the archesporial cell stage. It is very common, however, for the primary sporogenous cells to acquire small vacuoles (fig. 50), which merge into larger and larger vacuoles (fig. 5I), until finally the cytoplasm is only a thin membrane lining the walls of the cell. It stains less and less intensely as the process goes on. The chromatin becomes aggregated into fewer and larger masses, which lie closely appressed to the nuclear membrane, and which stain very deeply. The nucleolus soon becomes indistinguishable. The nucleus becomes irregular in outline and shrinks, and in turn almost disappears. At the same time, the primary parietal cell, connective cells, and surrounding epidermis undergo a similar disorganization. Such a process usually is not confined to a single loculus, or even to a single anther, but includes all the stamens of a flower. Apparently if the degeneration process is not intense such cells may continue dividing for a time, forming anthers with all parts in normal relation (figs. 55, 56). Finally the cells become too weakened to divide further, and are nearly or quite empty. Anthers may be found in this condition that have developed almost to the mother cell stage. In the end, the arrested stamens break down and disappear completely before the flower opens.

In other flowers the anthers may start normally, but individual cells in the sporogenous mass begin to degenerate, while the others, at least for a time, appear to continue normally (figs. 53, 54). Both cytoplasm and nucleus become more coarsely granular and very dense, and stain intensely. The protoplast pulls away from the cell walls, finally becoming only a shapeless dense mass in the central part of the cell. This process involves all the loculi of all the anthers of a flower, and may occur at any stage up to and including the mother cells.

Normal microspore mother cells round off evenly and uniformly when the anther enlarges, and stain moderately. Mother cells in the process of degeneration round off into irregular masses, and 
stain more or less intensely according to the degree of disorganization. These cells are capable of passing through the reduction divisions (fig. 6I), and chromosome number, spindles, and the tetrads formed appear to be normal in essential features, but they stain very deeply and the outlines are irregular.

Usually if the anther walls have developed unimpaired to the reduction stage, they can reach maturity and produce a normal appearing organ. Many, however, begin to collapse, and it is very common to find examples in which the walls have collapsed closely against the sporogenous tissue within, while the cells and walls are much wrinkled and distorted (fig. 6r). Earlier degenerations are likely to include all the stamens of a flower; later degenerations may include only one or two loculi of one anther, or only one or a few of the 6 anthers (figs. I I, I2). In one case in particular, one of the loculi of an anther had degenerated early and left only a small deeply staining spot at the side of an otherwise normal organ (fig. I $2 a$ ).

As already mentioned, the tapetum is involved along with the other parts. A few anthers have been observed in which the sporogenous cells had degenerated completely into dense shapeless masses, while the walls and tapetum had remained relatively unaffected; the wall cells were thicker than normal, and the tapetal cells had become much larger and projected like papillae against the contracted, disorganized, sporogenous tissue (fig. 59).

By the time reduction is completed, the tendency to degeneration has become so universal that only a few microspores appear normal. It is not uncommon to find even the spores of a tetrad in widely different stages of disorganization; one or two will appear almost normal, while the others are mere masses of stain (fig. 62). In such cases it is certain that spores that do not stain so intensely are really affected. Spores that survive liberation from the tetrad may shrivel up, with the cytoplasm more and more closely packed about the diminishing nucleus, until finally nothing is left but the wall with a little mass collapsed against one side (figs. $63,65,66)$.

Very many spores proceed to wall formation and the usual divisions to complete the male gametophyte. Only in a few 


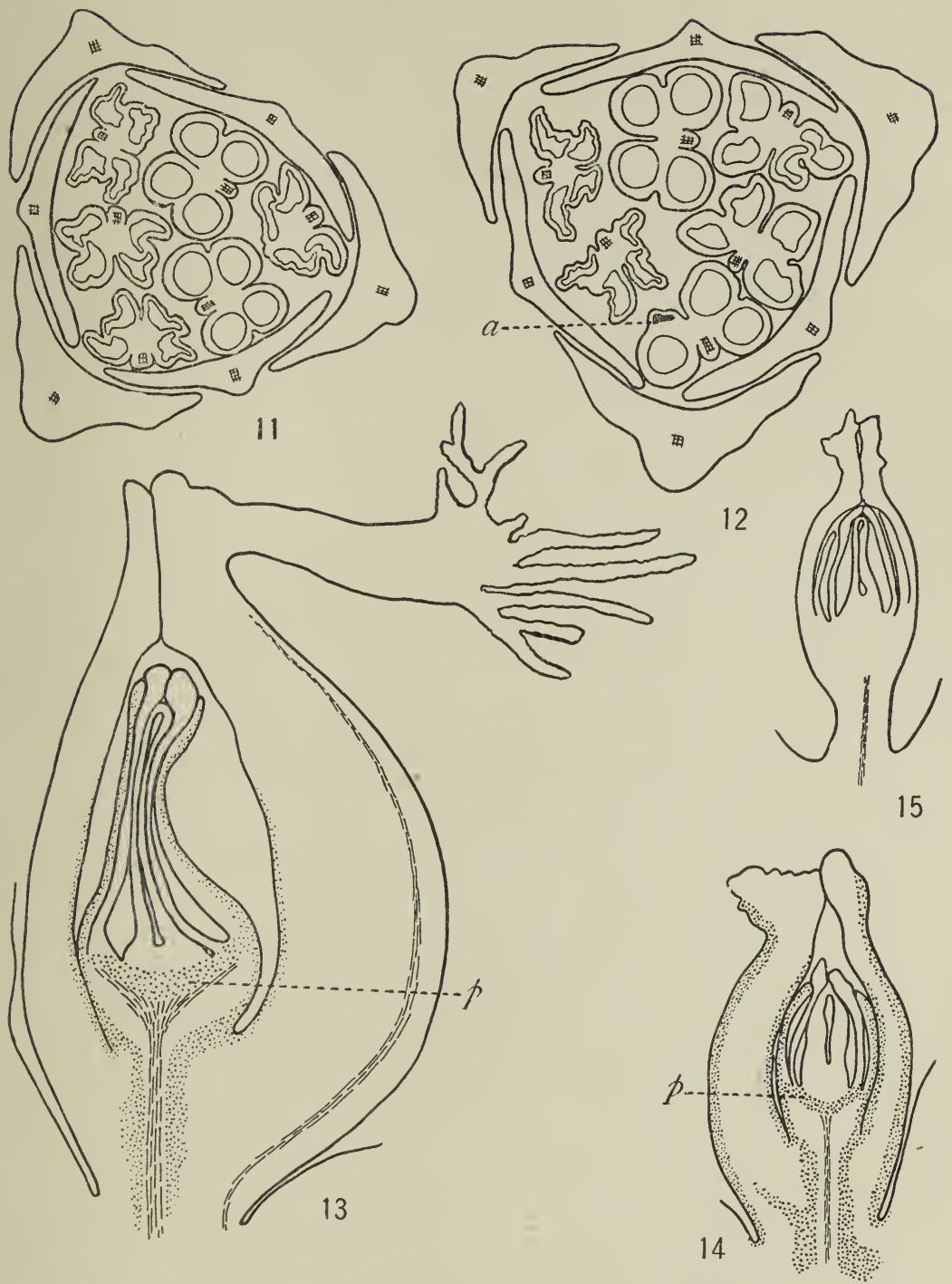

FigS. II-I5.-Various degrees of degeneration in flower: figs. II, I2, transverse sections of flowers at tetrad stage of microspores, showing indiscriminate failure of anthers; at $a$, fig. I2, a loculus disorganized early, while other three are developing normally; fig. I3, ovary well developed, ovule just beginning to collapse, and embryo $\mathrm{sac}$ with small amount of completely disorganized endosperm; fig. I4, both embryo sac and ovule disorganized; fig. I5, ovary in which degeneration began so early that nothing remains but dried remnants; shaded parts in figs. I3, I4 indicate thickened impervious cells, particularly chalazal plate $(p)$; ending of ovular vascular bundle also shown; figs. II, I2, $X_{50}$; figs. I3-I5, $X_{155}$. 
instances, however, do the cells produced look as if they might be normal. The cytoplasm is much vacuolated, and the nuclei are not distinct, even in the best of preparations (figs. $67,68,72,73$ ).

HyPERTROPHY OF POLLEN GRAIN.-Those grains that appear most nearly normal have little or no starch (fig. 67). Pollen grains that have proceeded to full wall development and generative cell formation begin to enlarge until about twice normal volume (fig. 68). In all such there is considerable accumulation of starch grains, and in some the cell is tightly packed with relatively enormous grains (fig. 69). Whenever the nuclei show at all, they are irregular in outline, poorly defined, and almost uniform in texture. Later, the starch is dissolved, and the contents of the pollen grain become more and more homogeneous, until in the end the grain is filled with a granular substance staining deeply and uniformly throughout. In the best preparations, some of these cells still showed the remains of the nuclei; but there is little doubt that they are destined to go to pieces (figs. 70-73). In every case the tube nucleus was irregular and difficult to trace, but often the two male nuclei, although very small, still held their shape and showed separate chromatin masses. Usually, however, only deeply and characteristically staining masses indicate the remains of the nuclei (figs. $7 \mathrm{I}, 72,75$ ).

"Pollen tube" FORMATion.--Hypertrophy of the pollen grains may be due to high osmotic pressure set up in the disintegrating contents. The starch formation undoubtedly is pathological. The conditions in the cell that induce starch formation probably also cause other changes, which lead to greatly increased osmotic pressure, which is further increased by the solution of the starch. Very frequently these large pollen grains put out pollen tubes through all three of the germ pores. These tubes may remain mere bulbs (fig. 72), or they may become many times the length of the cell producing them, and are always almost solidly filled with the dense homogeneous contents of the mother cell (figs. 74, 75). Often the disorganizing nuclei migrate into the tubes, and the pollen grain may be almost entirely emptied (fig. 74). The tubes often become inflated at the end, as if under pressure, and it appears that they sometimes burst. 
The explanation of these tubes seems to be that the high osmotic pressure set up in the pollen grain literally blows the distensible intine out through the germ pores, and continues elongation of the tube as long as the pressure is maintained. Presently the pressure goes down and the process ceases. It may be that the retention of some semblance of organization by the nuclei indicates that the cell is not dead, and that tube formation is a weak abnormal growth process. Finally, the contents of the grain begin to shrivel (fig. 74), the walls become wrinkled and collapse, and the cell dries up. By the time the anthers open, little or no trace of the pollen tubes remains, and the nuclear material is no longer distinguishable. I would estimate that 99 per cent of the pollen grains undergo some such degeneration process. Very infrequently one can find a grain of normal size with the nuclei clearly outlined, lying among the hypertrophied grains, and occasionally one or two of the loculi of an anther will contain seemingly normal grains, while the remaining loculi are filled with the large cytolyzed grains.

Fungus INVASIONS. - Such a mass of disorganizing cells would seem to be particularly favorable material for the growth of saprophytes. In every dehisced anther sectioned there was an abundant growth of an unidentified fungus. The septate hyphae ramify everywhere through the pollen chambers among the pollen grains, and in a very few instances were seen penetrating pollen grains through the germ pores (fig. 70), but with the appearance of a chance entrance, rather than a definite exploitation of the contents of the grains. It may be stated confidently that the fungus does not attack unopened anthers, for it/ never was present until after the anthers had opened. In those anthers where the fungus had been developing longest and had formed a felt of hyphae, it had produced a great abundance of minute spores.

DEgenerations in OVARY.-Degenerations just as widespread and devastating occur in the ovary also. They do not begin so early as in the anthers, never having been observed with certainty before reduction is completed (figs. 3I, 32), although there are faint suggestions that even during the second reduction division the cells may not be entirely healthy. The non-functioning megaspores seem to degenerate prematurely, although this is by no 
means an unusual feature in angiosperms. With the beginning of enlargement of the functioning megaspore the degeneration process becomes apparent (figs. 3I, 32). It is always characterized by increasing density of both cytoplasm and nucleus, plasmolysis of the cytoplasm, and final collapse into a distorted strand in the center of the cell (figs. 36, 37). The disturbance occurs with increasing frequency through the various stages of embryo sac formation, 2- (figs. 39, 40, 4I), 4- (fig. 43), and 8-nucleate (fig. 45) stages being found in more or less advanced degeneration, until by the time the sac should be mature, scarcely one remains untouched. In all the sections made and examined, I have seen just one normal appearing embryo sac. It is not a case of having overlooked the stage, for repeatedly late buds and open flowers showed the remains of sacs in all stages of disorganization (fig. 47).

At first, and in early embryo sac stages, only the sac itself is involved, but later the entire ovule becomes shriveled, with the individual cells deeply staining. If the process has begun early enough, it involves the entire ovary also. An open flower, therefore, may show all parts of the ovary normal except the embryo sac (fig. I3), or both embryo sac and ovule may be degenerating (fig. I4), or the entire ovary may be shriveled up, brown, and dead, a mere husk projecting up from the base of the flower (fig. I5).

Degenerations do not halt here, but may attack those ovaries in which embryo formation has begun. At any stage in the development of the fruit the ovule may collapse about the embryo and endosperm, which then take on the characteristic dense, deeply staining appearance. The ovary itself appears sometimes to continue normal development, at least for a time, or it may follow the other parts in degeneration. Certainly not more than Io per cent of the flowers examined in section contained embryos, and of these not more than ro per cent had the appearance of being able to reach maturity in a normal manner.

It is very striking that in every case a plate of dense impervious cells, several layers thick, was formed across the chalaza, connecting at the edges with the impervious layer over the outer integument and the ovary walls. Other and irregular patches of similar tissue appear in the funiculus, often seeming to involve 
even the cells of the ovular vascular bundle (figs. I3, I4, 20). This bundle flares out against the lower side of the impervious chalazal plate (fig. I3), and there is no passage of normal cells anywhere connecting it with the nucellus. The lower end of the bundle terminates blindly in a patch of permanently thin-walled parenchyma, with absolutely no connection with the vascular system traversing the peduncle and branching to supply the other parts of the flower (figs. I9-2I). Below this parenchyma, between the traces to the sepals and petals, and removed by 8-io parenchyma cells from the end of the ovular bundle, the bundle of the peduncle terminates in a broad axial mass of short tracheids. One thinks of the patch of parenchyma as a reservoir, filled from the bottom by the bundles of the peduncle, and emptied by an ovular bundle dipping into the top.

Degenerations in ENTIRE INFLORESCENCE.-Degenerations are not always confined to scattered flowers, but may involve all the flowers, especially the terminal portions of large or late inflorescences. The earlier in the development of the inflorescence that the degeneration processes set in, the larger is the number of flowers involved.

ABscissions.-Accompanying these degenerations is a strong tendency for parts to absciss. There is a definite abscission layer formed near the base of the peduncle (fig. I6), which leads to dropping off of those flowers in which extreme early degenerations have appeared. A ring of epidermis remains thin, and the underlying cortical cells remain meristematic. The exact method of operation has not been followed; it is probable that the mechanism is called into activity by the same causes that result in failure of the other floral parts.

The fully developed filament of the stamen is a short thick stalk, traversed by a small vascular bundle. All the mature stamens that were observed were either entirely separated from the flower, or at least physiologically separated, by disorganization of the upper end of the filaments. The epidermis and cortical cells break down, leaving the anther attached by the vascular bundle only (fig. I9a). Soon this is severed also, and the anther is held in the flower only by the floral envelop, to be dropped out upon 
blooming. The stump of the filament continues disorganizing until finally only frayed out, dried remnants remain at the point of insertion.

Results OF DEGENERATIONS.--Where degenerations involve both stamens and ovary at an early age, the entire bud drops before opening. A large percentage of the flowers of an inflores-

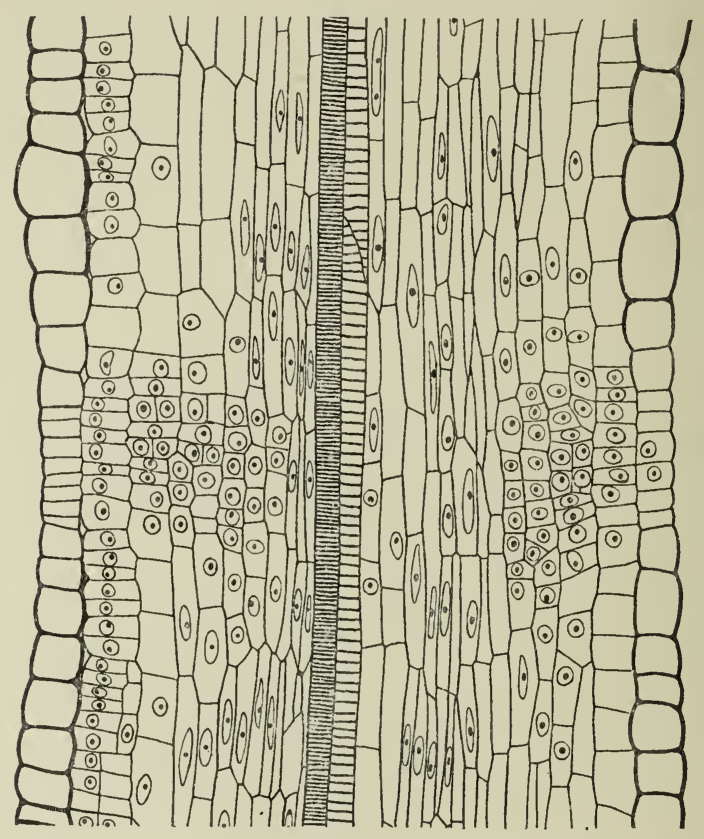

FIG. I6.--Longitudinal section through abscission region of peduncle; cells of epidermis are strongly thickened, and those of cortex are for the most part differentiated beyond point of further division, except in definite abscission zone, where divisions are still in progress; note large number of recently divided cells in subepidermal layer on left side; their subsequent elongation will produce the strong curvature of peduncle; $\times 350$.

cence is lost in this way. Where the degenerations involve only the stamens or only the carpels, or when beginning later in the development of the flower, 4 distinct types of mature flowers are produced, with all gradations between.

I. Functional staminate flowers, in which any number of stamens, from one to all, reach maturity, although their products 
usually are not functional. The ovary usually is well developed, but the embryo sac is sterile by degeneration. The sepals and petals are about equally developed; they have performed their function in protecting the essential organs in the bud, and make no

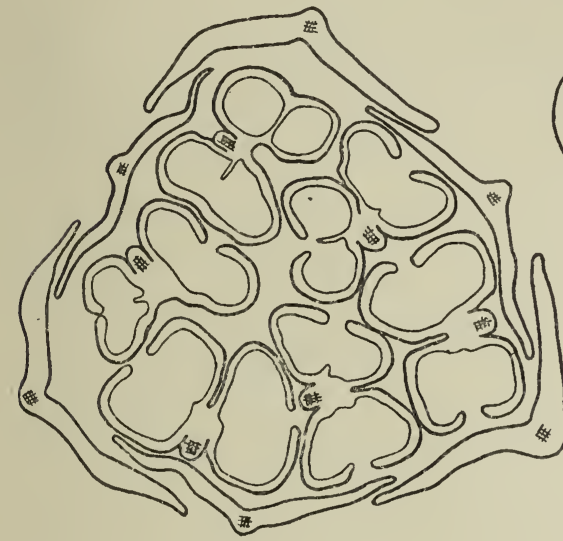

17
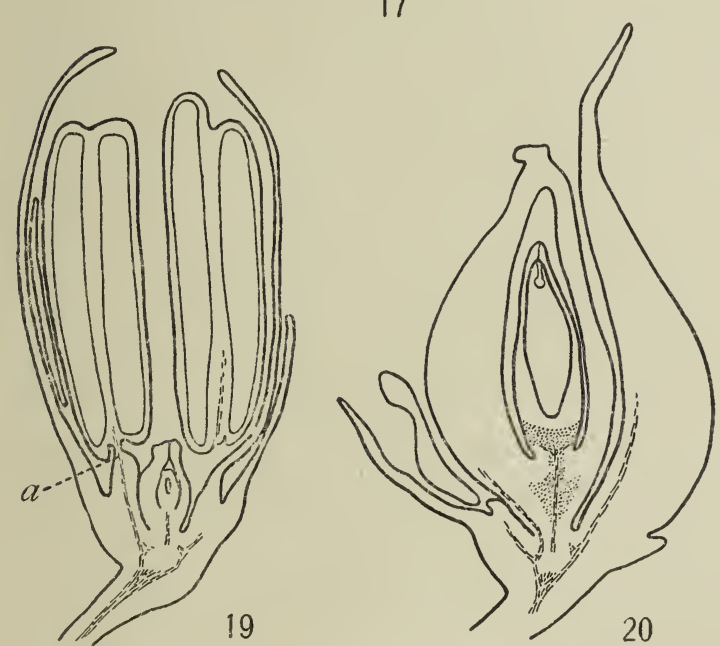

Figs. 17-21.-Types of mature flowers: fig. I7, transverse section, and fig. I9, longitudinal section of a functional staminate flower; ovary is present but sterile by degeneration; anther on left in fig. I9 nearly severed by disorganization of filament at $a$; fig. I8, transverse section, and fig. 20, longitudinal section of functional ovulate flower at early stage of embryo development; stamens degenerated and disappeared before flower opened; fig. 2I, longitudinal section of a sterile flower; stamens obliterated and ovule sterile by degenerations; figs. I7, I8, $\times_{30}$; figs. I9-2I, $\times 18$. 
further growth. The flowers have accomplished their purpose with the development of pollen, defective though that may be, and soon wither (figs. I7, I9).

2. Functional ovulate flowers, from which all the stamens have been eliminated by degeneration before the opening of the flower. In such flowers the stamens frequently disappear so early that the points of insertion are no longer discernible, and even the vascular traces have almost disappeared. An embryo begins to develop, and endosperm formation starts, although subsequently degeneration may overtake it, resulting either in death of the entire flower, or in development of a pseudo-parthenocarpic fruit. The sepals remain small, but the petals enlarge as protective organs and develop the characteristic tubercles (figs. I8, 20).

3. Bisporangiate flowers, containing both functional ovary and functional stamens. They are very rare; I have sectioned two such, and these had only one or two stamens each.

4. Completely sterile flowers, where degenerations have occurred in both stamens and carpels early enough to cause complete elimination of the former, but not severe enough to cause the flower to drop before blooming. The ovary may be in any condition from fully developed, with only the embryo sac defective, to a mere dried remnant (fig. 2I).

\section{Conclusions as to significance of degenerations}

Such degenerations as have been described look toward the complete elimination of either the stamens collectively or the carpels. The process seems very severe, and results in a high mortality, not only of flowers, but of the developing fruits as well. It is a case of degeneration during the process of development, and is not to be confused with arrested development, such as occurs in the production of staminodia, and which looks toward reduction in the number of organs in the cycle involved.

The term dioecism has a very different meaning when applied to spermatophytes and when applied to cryptogams. In the latter it is assumed that separation of the sexes to distinct male and female gametophytes is a phenomenon based on heredity, and determined by chromatic constitution, and that the separation 
occurs during the reduction divisions. When the differentiation is pushed farther back, however, until the sporophytes producing the two kinds of spores are likewise differentiated, it is difficult to see how chromatic constitution can be made to explain the situation. It is to this later and secondary phase of sex segregation that the term dioecism is applied in seed plants. The view has been expressed in scattered papers that the particular species under investigation have been rendered diclinous by failure of either the stamen or the ovules to produce functional gametophytes, and that this process has been carried a step farther, to the complete suppression of the functioning stamens in some (ovulate) plants, and to the complete suppression of functioning ovaries in other (staminate) plants. This view has been occasioned by the discovery that more or less perfect essential organs may produce few or no functional sexual products.

Rumex seems a particularly favorable group for the study of this process, and it is believed that it shows convincing evidence for the origin of dicliny, and finally of dioecism, by degenerations during ontogenesis. The members of the section Lapathum, including $R$. crispus, are variously described in manuals as having hermaphrodite, polygamo-monoecious, polygamo-dioecious, andromonoecious, gyno-dioecious, etc., flowers, while those belonging to the Acetosa section are described as dioecious. In $R$. crispus, at least, the appearance of the mature flowers evidently is misleading, for sections show that the apparently perfect flowers are almost invariably functionally staminate; the apparently staminate flowers are really such; while the apparently ovulate may be either functionally ovulate or completely sterile. These conditions are brought about by degeneration at various stages in oogenesis and spermatogenesis, and not by arrested development. The result, even in the seemingly perfect flowers of $R$. crispus, is physiological dicliny.

Rотн (8) found in species of section AcETosa, which are usually exclusively dioecious, that sometimes hermaphrodite and even staminate flowers are produced, but that the pollen is defective in every case; others have found the same situation. All the species in section LAPATHUM that he investigated produced hermaphrodite 
flowers at first, and ovulate flowers almost exclusively later in the season. He found numerous instances of degenerating embryo sacs in $R$. Acetosa. I have examined a great many sections of $R$. Acetosella, and found no instance of such behavior. It would seem that degenerations in the ovary are much less frequent in the dioecious species than in the so-called hermaphrodite, and that when the ovulate plants occasionally produce stamens, all the pollen is functionless.

The conclusion is that Rumex formerly produced only hermaphrodite flowers, and that by degenerations in the stamens and in the carpels the condition has been attained such as is found in $R$. crispus, and the species of section LAPATHUM in general, where the inflorescence contains a mixture of physiologically staminate, physiologically ovulate, a few bisporangiate, and many completely sterile flowers. This is physiological dicliny. The process has been carried farther in some forms, resulting in segregation of the staminate and ovulate flowers to separate plants, as is now the case in the species in section Acetosa. That these latter forms have been derived from bisporangiate or monoecious ancestors is indicated by the occasional production of stamens on "ovulate" plants. That this derivation has been due to degenerations is indicated by the sterility of the staminate structures when they are formed.

It seems clear that the stamens are more readily eliminated from the flowers than are the ovules. They start degenerating earlier in their development, and it is very common for all trace of them to be lost by the time the flower opens, while the ovules invariably persist in physiologically staminate flowers, and very frequently are defective only in the embryo sac.

It is probable that the degeneration processes favor the occurrence of apogamy. Not only does degeneration result in elimination of stamens from many flowers, but it results also in sterility of the pollen that is produced by normal anthers. Dioecism would render pollination by the small amount of pollen remaining normal a very uncertain process. Finally, it is altogether possible that when the degeneration process in the ovary is but weakly manifested, it may interfere with reduction in the megaspore mother 
cell, and may account for the long wait in the prophase of the heterotypic mitosis, and the subsequent completion of the division as a typic mitosis, as has been repeatedly reported for well marked apogamous plants.

The strong tendency to failure in the sexual process may also contribute to the development of highly successful methods of vegetative propagation. Nearly all the species of section LAPATHUM perennate by strong storage tap roots crowned by a short stem region, or by storage rhizomes, and all propagate very freely by detached fragments of these underground stems. $R$. Acetosella propagates by long lateral roots which produce new plants at intervals. It is a striking fact that patches of the plant are dense growths of almost exclusively staminate or ovulate plants. This is what would be expected to result from such vegetative propagation, and would be a curious segregation to result from plants produced to any great extent from seeds. All the evidence I have seen points to apogamy in $R$. Acetosella; seed production is very scanty in proportion to the number of flower buds, and a large percentage of the fruits are empty. A considerable number of seedlings scattered about in patches of ovulate plants indicates that many of the seeds are viable.

From the great number of diclinous angiosperm flowers that contain remnants of the other organs, it seems very probable that the degeneration processes here described are of widespread occurrence, and are scattered throughout the group from the lowest to the highest forms. It is planned to make a study of dicliny in the future, in the effort to substantiate or disprove this theory of the origin of dicliny as the result of degenerations.

The cause of these degenerations is not known. The few authors who have discussed the problem all agree that faulty nutrition is important, if not as the direct cause, at least in producing conditions that call the phenomenon into activity. Hofrmann (5) supposed that the embryos of $R$. Acelosella and other dioecious plants are sexless, and that sex is determined in the early stages of the seedling by the conditions under which they germinate. GärTnER (4) used the evidence in the reverse order, and thought 
that degenerations in the stamens and ovules are "caused by the inherent tendency in the species to become dioecious." "Faulty nutrition" is so indefinite and vague, and includes such a wide range of possibilities that it can scarcely be considered as an adequate explanation. It is more probably a condition which calls into greater activity certain fundamental and at present unknown causes of degeneration that are always present in a wide range of angiosperm forms. It is barely possible that the peculiar detached vascular bundle of the ovule may be responsible for the failure of the ovule in later stages. This bundle never has been found connected with the general vascular system of the peduncle, even in those infrequent instances when the embryo and endosperm seem to be developing normally. If this should prove to be the immediate cause for later degenerations in the ovule, there still remains no hint of the cause for the failure of the ovular vascular bundle to make proper connections.

Strasburger (Io) concluded from his study of the species of EuALCHEMILla that sterility is the result of excessive mutation. It seems clear that sterility, partial or complete, results from degenerations, and probably such degenerations are the only morphological causes of sterility. It might follow then that excessive mutation is the cause of sterility, or it may be that mutating species are only more susceptible to degenerations.

JEFFREY (6) believes that sterility is the result of hybridization. Again, it is a question whether hybridity is a fundamental cause, or only produces physiological conditions that activate a more or less latent tendency to degenerations. If hybridity is the underlying cause of the degenerations that lead to sterility, and the theory that these degenerations lead to dicliny, apogamy, and the development of successful methods of vegetative propagation should prove to be correct, it would seem to follow that all hybrids are tending toward these states. Probably the evidence would not support this reasoning. It is more probable that there exists no causal relation between the hybrid state and degenerations, except as physiological conditions in hybrids favor such processes.

Dorsey (2) concludes from a study of grape hybrids that "hybridity is not necessarily a cause of sterility," and that "pollen 
sterility in the grape is only a step toward functional dicliny." All the scanty published evidence I have seen seems to support this conclusion.

\section{Summary}

I. Organogeny is normal, with slight delay in appearance of petals and carpels.

2. The megaspore mother cell produces a tetrad of megaspores, the innermost of which functions. The haploid chromosome number is 32 .

3. The embryo sac is of the ordinary 8-nucleate type.

4. Microsporogenous tissue is formed from the primary sporogenous cell by $3-4$ successive divisions, and reduction is normal. The haploid chromosome number is 32 .

5. The mature pollen grain contains two male nuclei, the progeny of a definite generative cell.

6. There is good negative evidence both for and against the occurrence of fertilization. This raises the question whether some of the megaspore mother cells may not undergo reduction, while others only simulate reduction and give rise to a diploid embryo sac, the latter only producing embryos by the apogamous development of the egg.

7. Widespread degenerations occur: $(a)$ in any or all of the anthers, at any stage from the sporogenous initial to the mature pollen grain, and may involve only the sporogenous tissue and its products, or the entire anther; (b) in the ovary, at any stage from the functioning megaspore to the maturing fruit, and may involve only the embryo sac, or both embryo sac and ovule, or the entire ovary; (c) in entire inflorescences.

8. Most pollen grains undergo cytolysis, with abundant starch formation, conspicuous enlargement, and the formation of "pollen tubes."

9. Only a small percentage of pollen grains and embryo sacs have the appearance of being functional.

Io. An unidentified fungus invades the anthers after dehiscence, ramifying among but rarely penetrating the pollen grains.

II. There is a definite abscission layer near the base of the peduncle, cutting off either before or after blooming those flowers 
in which both stamens and ovary are early involved in strong degenerations. There is also a degeneration of the filament cells, severing the maturing anthers.

I 2. Four types of mature flowers are produced by these degenerations: (a) physiologically staminate, although the pollen may or may not be functional (the ovary is functionless); (b) physiologically ovulate, the stamens having been completely eliminated by degeneration; (c) bisporangiate, having both stamens and ovary functional (very rare); $(d)$ completely sterile, having functionless ovary, and stamens completely eliminated.

I3. It is suggested that these degenerations may be of widespread occurrence, and probably are the cause of $(a)$ dicliny, and finally dioecism, and $(b)$ apogamy, and that $(c)$ they favor the development of successful methods of vegetative propagation.

I4. The cause of such degenerations is as yet unknown. It is suggested that deficient nutrition, excessive mutation, and hybridity bear no causal relation to degeneration, except as they may create physiological conditions favorable for it.

I wish to thank Dr. J. M. Coulter, Dr. C. J. Chamberlain, and Dr. W. J. G. LAND for their interest and assistance throughout the course of this investigation.

Ewing Christian College

Allahabad, INDia

\section{LITERATURE CITED}

I. Bonnett, Jean, Recherches sur l'évolution des cellules-nourricières du pollen, chez les Angiospermes. Archiv. Zellf. 7:604-722. pls. 39-45. figs. I7. I9I 2.

2. Dorsey, M. J., Pollen development in the grape, with special reference to sterility. Univ. Minn. Agric. Exper. Sta. Bull. no. I44. pp. I-6o. pls. I-4. I9I4.

3. Fink, Bruce, Contributions to the life-history of Rumex. Minn. Bot. Studies, Series II, part 2, pp. I37-53. pls. 9-I2. I899.

4. Gärtner, J., cited in Darwin's "Animals and plants under domestication," Vol. II, p. I44 (2d edition, D. Appleton and Co.).

5. Hoffmann, H., Über Sexualität. Bot. Zeit. 43: I45-I53, I6I-I69. I 885 .

6. Jefrerey, E. C., The mutation myth. Science, N.S. 39:488-49I. I9I4.

7. Overton, J. B., Über Parthenogenesis bei Thalictrum purpurascens (Vorläufige Mitteilung). Ber. Deutsch. Bot. Gesells. 22:274-283. pl. I5. I904. 
8. Roth, Franz, Die Fortpflanzungsverhältnisse bei der Gattung Rumex. Diss. Bonn. pl. I. I907.

9. Strasburger, Eduard, Die Angiospermen und die Gymnospermen. Jena. I879 (pp. 3-9).

го. - Die Apogamie der Eualchemillen, und allgemeine Gesichtspunkte, die sich aus ihr ergeben. Jahrb. Wiss. Bot. 41:88-164. pls. I-4. I905.

\section{EXPLANATION OF PLATES XVII-XIX}

Figs. 22-75 were all drawn at an initial magnification of $X_{1460}$, with the exception of figs. 26 and 60 , which were $\times 4400$; all figures have been reduced one-half.

FIG. 22-Longitudinal section of young nucellus, showing archesporial cell terminating a definite axial row.

FIG. 23.-Archesporial cell divided into primary wall cell and megaspore mother cell.

Fig. 24--Nucellus with 2 megaspore mother cells, both in prophase of heterotypic mitosis.

FIG. 25.-Megaspore mother cell in prophase of heterotypic mitosis; wall cells have divided periclinally.

FIG. 26.-Diakinesis in megaspore mother cell, showing 32 pairs of chromosomes, the haploid number; reconstructed from 3 sections.

FIG. 27.-Spindle of heterotypic mitosis in megaspore mother cell; plasmolysis may possibly indicate initial stage of degeneration.

FIG. 28.-Normal tetrad of megaspores.

FIG. 29.-Early degeneration of outer 3 megaspores of tetrad.

FIG. 30.--Inner cell has preceded outer in homoiotypic mitosis.

FIG. 3I.-Early degeneration of functioning megaspore.

FIG. 32.-Degeneration of functioning megaspore at a slightly later stage.

FIG. 33.-Normal growth of functioning megaspore.

Figs. 34, 35.-Normal functioning megaspores fully enlarged.

FIGS. 36, 37.-Degeneration of fully enlarged functioning megaspores.

Fig. 38.-Normal 2-nucleate stage of embryo sac.

FIG. 39.-Early stage in degeneration of embryo sac in 2-nucleate stage.

Figs. 40, 4I.-Same, more advanced.

Fig. 42.- Normal 4-nucleate stage of embryo sac.

Fig. 43.-Degeneration of embryo sac in 4-nucleate stage.

FIG. 44.-Normal 8-nucleate stage of embryo sac just beginning mature organization.

FIG. 45.-Degeneration of embryo sac in 8-nucleate stage.

Fig. 46.-Normal fully developed embryo sac.

FIG. 47.-Fully developed embryo sac in advanced degeneration, apparently after a long wait for fertilization.

FIG. 48.-Transverse section of portion of a young anther, showing archesporial cells.

FIG. 49.-Archesporial cell divided into primary parietal cell and primary microsporogenous cell. 
FIG. 50.-Primary microsporogenous cells beginning to degenerate; anticlinal division preceded usual periclinal in archespore.

FIG. 51.-Primary microsporogenous cell in advanced degeneration.

FIG. 52.-First division in normal primary microsporogenous cell.

FIG. 53.-Degeneration restricted to a single cell (in transverse section) of early microsporogenous tissue.

FIG. 54.-Degeneration of isolated cells in later microsporogenous tissue.

FIG. 55.-Advanced degeneration of entire mass of microsporogenous cells; wall cells are also involved.

FIG. 56.- Same at a later stage of development; wall cells nearly normal.

FIG. 57.-Portion of normal anther at synapsis of microspore mother cells.

FIG. 58.-Same stage, with premature degeneration of tapetum.

FIG. 59.- Same stage, with microsporogenous tissue completely disorganized; middle wall layer and tapetum greatly enlarged.

FIG. 60.-Diakinesis stage of heterotypic mitosis in normal microspore mother cell, showing 32 pairs of chromosomes, the haploid number; reconstructed from 2 sections.

FIG. 6r.-Transverse section of loculus of collapsed anther, in which degenerating sporogenous tissue has just completed reduction; tapetum shows variety of nuclear situations, and is still functional.

FIG. 62.-Tetrad of microspores in various stages of degeneration.

FIG. 63.-Probably normal disorganization of tapetum at a time when the microspores are well differentiated, although apparently beginning to degenerate.

FIG. 64.-Apparently normal microspore.

FIG. 65.-Microspore degenerating.

FIG. 66.-Microspore with walls completely differentiated, in advanced degeneration.

FIG. 67.-Apparently nearly normal pollen grain with generative cell organized. tion.

FIG. 68.- Same, showing beginning of hypertrophy and starch accumula-

FIG. 69.-Hypertrophied pollen grain, packed with large starch grains.

FIG. 70.-Hypertrophied pollen grain with contents beginning to disorganize, penetrated by a fungus hypha.

FIG. 7I.-Hypertrophied pollen grain with contents in advanced disorganization.

FIG. 72.- Same, with beginning of pollen tube formation.

FIG. 73.- Hypertrophied pollen grain, with contents disorganized to homogeneous mass and beginning to collapse.

FIG. 74.-Portion of hypertrophied pollen grain with well developed pollen tube; disorganized nuclei still in grain.

FIG. 75.-Hypertrophied pollen grain with long pollen tube into which remains of disorganized nuclei have migrated. 

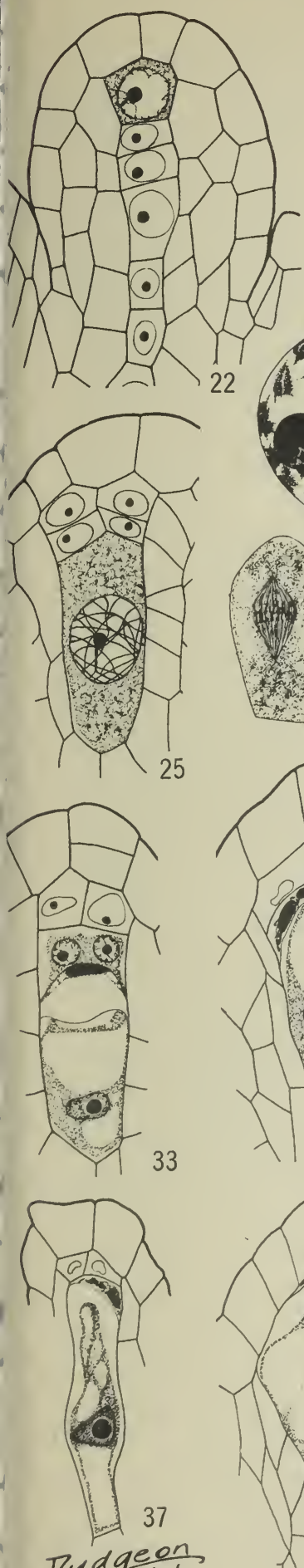

Zudgeon

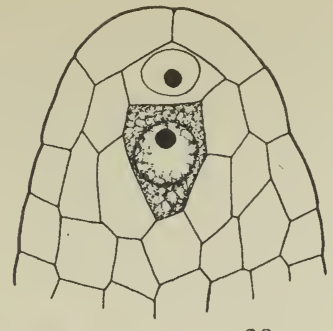

23
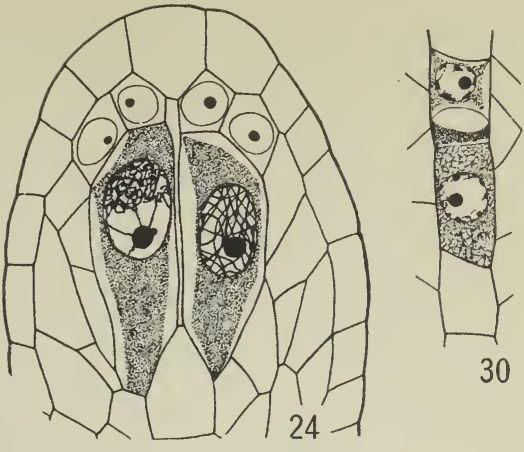

30
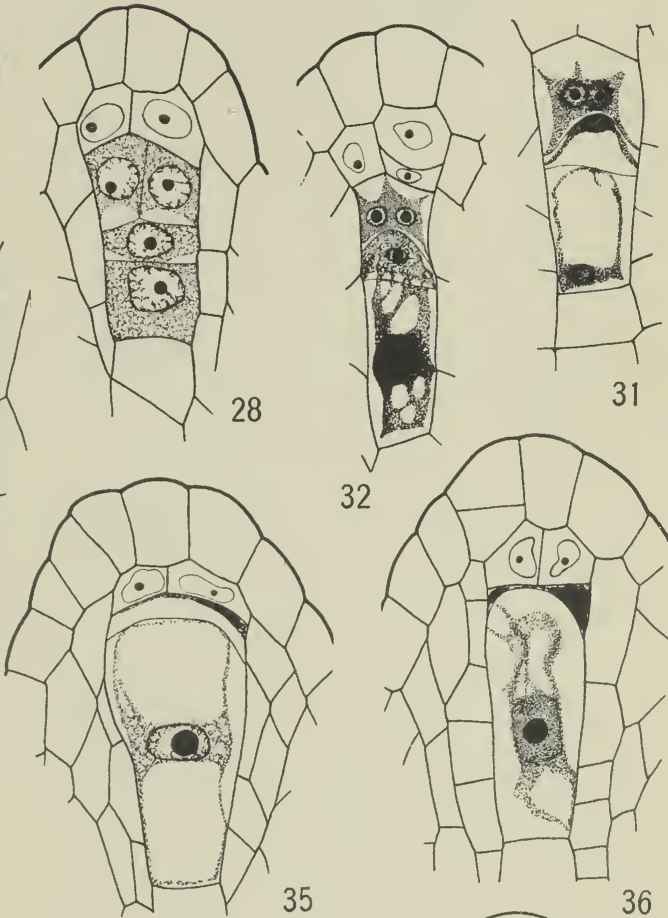

34

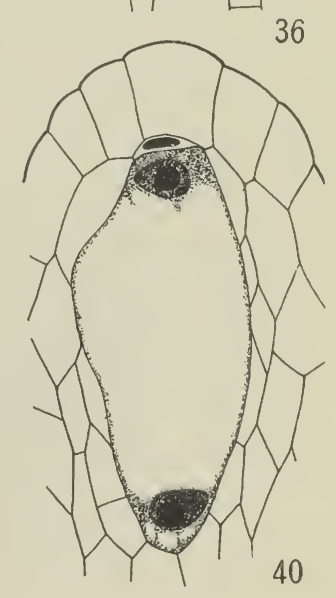

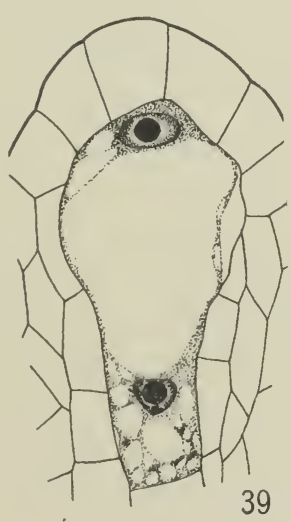

39 


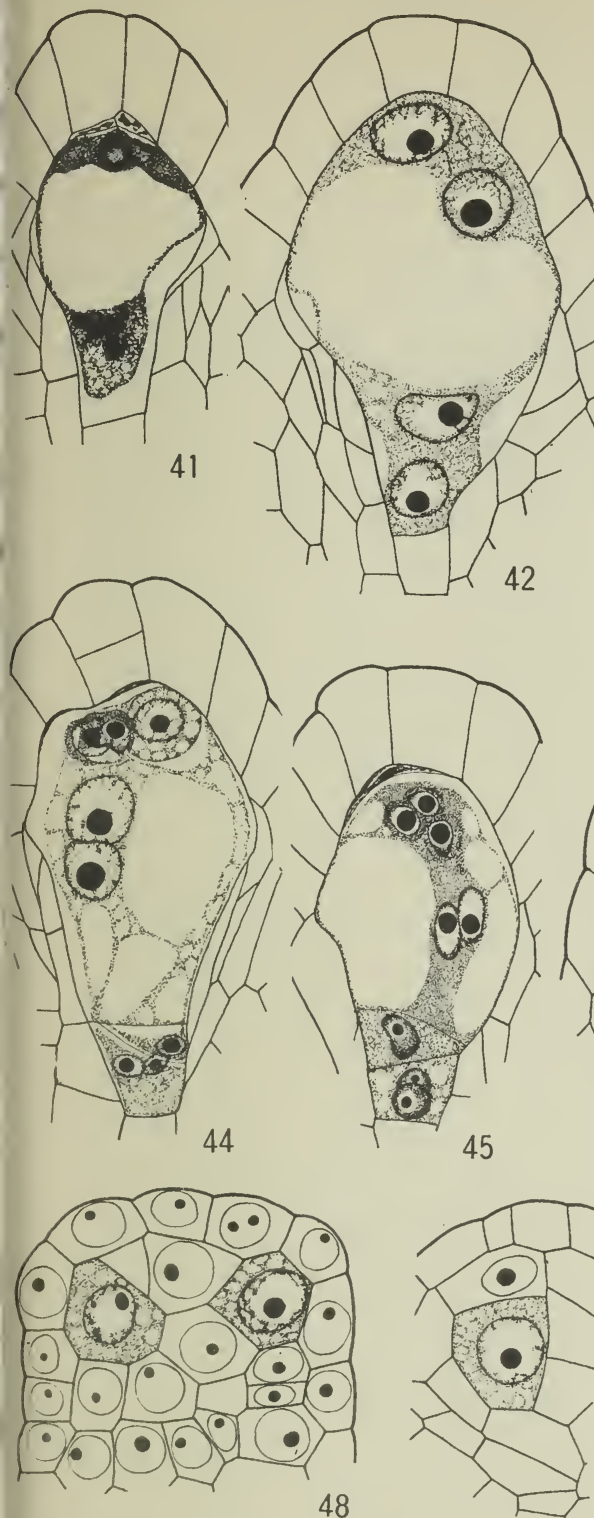

48
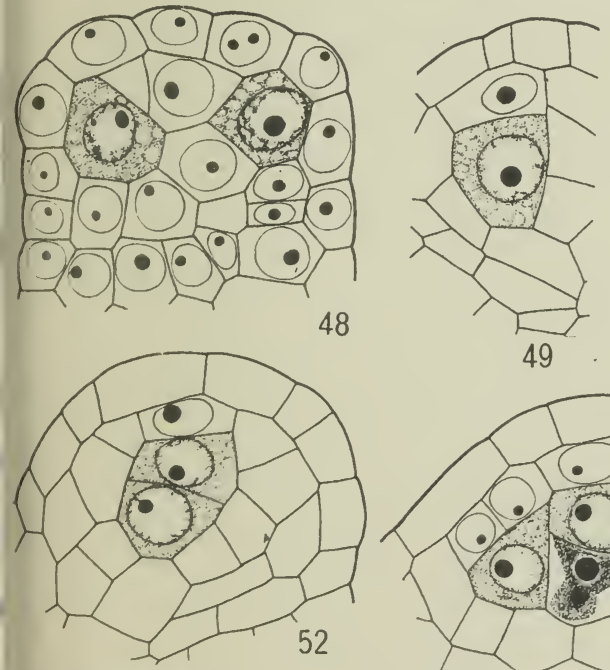

Ruageon
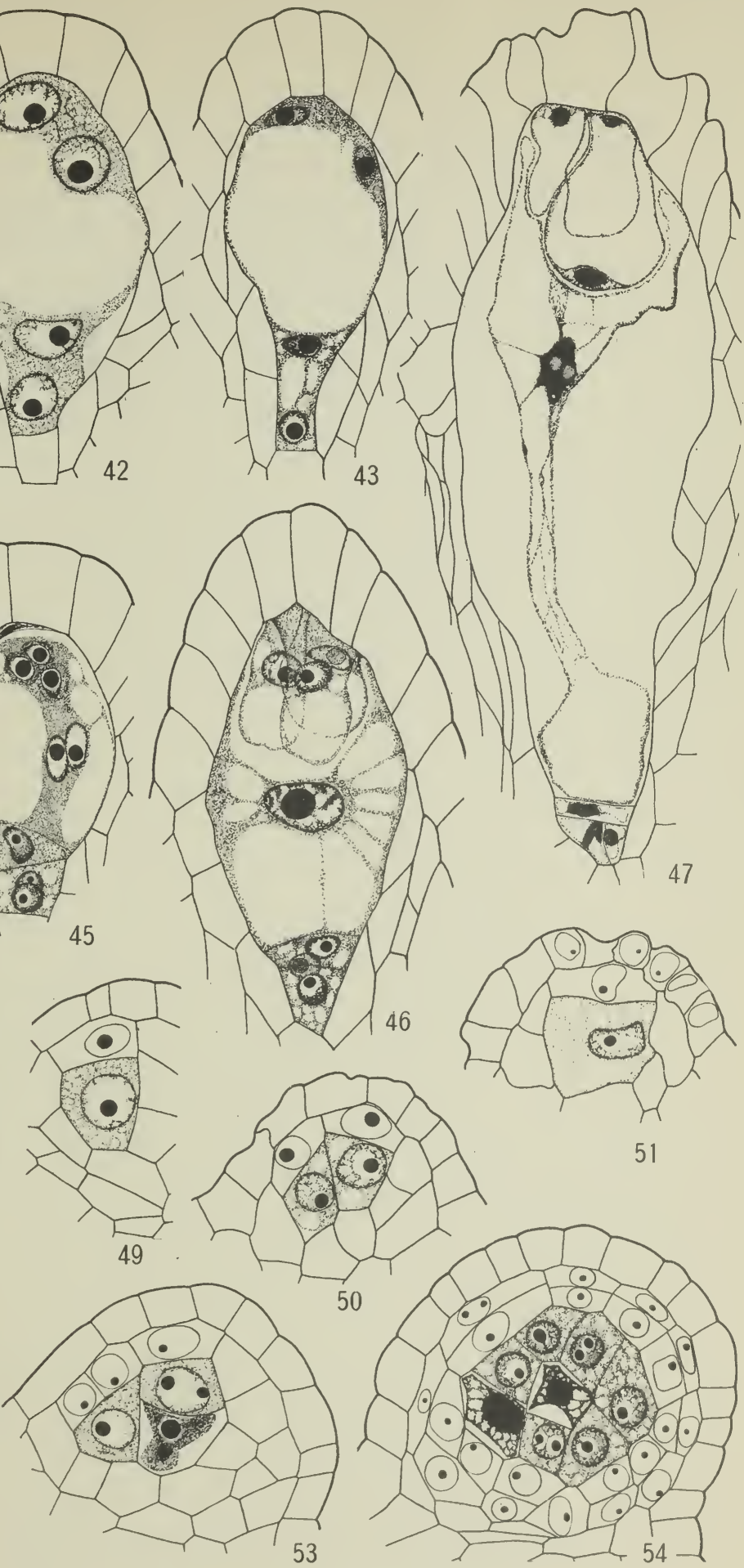

51
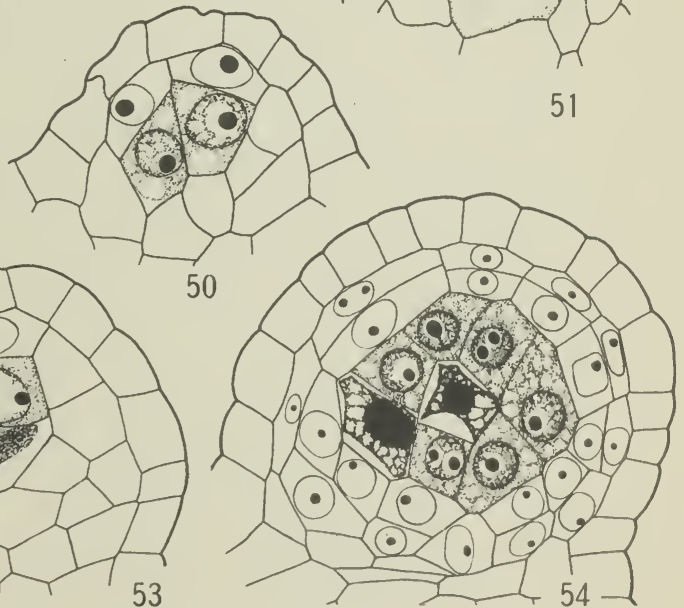

DUDGEON on RUMEX 

